\title{
Heat flow map and geothermal resources in Mexico ${ }^{\text {th }}$
}

\section{Mapa de flujo de calor y recursos geotérmicos de México}

\author{
Rosa-Maria Prol-Ledesma*a, Juan-Luis Carrillo-de la Cruz ${ }^{\mathrm{b}}$, Marco-Antonio Torres-Vera ${ }^{\mathrm{b}}$, Alejandra-Selene Membrillo-Abad ${ }^{\mathrm{b}}$, \\ Orlando-Miguel Espinoza-Ojeda ${ }^{\mathrm{c}}$ \\ a Instituto de Geofísica, Universidad Nacional Autónoma de México, Cd. Universitaria, Cd. De México, CP 04510, México. \\ ${ }^{b}$ Posgrado en Ciencias de la Tierra, Instituto de Geofísica, Universidad Nacional Autónoma de México, Cd. Universitaria, Cd. De México, CP 04510, México. \\ ${ }^{c}$ CONACyT - INICIT, Universidad Michoacana de San Nicolás de Hidalgo, Morelia, Michoacán, CP 58060, México
}

\begin{abstract}
Heat flow maps are a powerful tool for regional exploration of geothermal resources. Mexico is one of the main producers of geothermal energy and the search for undiscovered resources at a regional level should be based on heat flow values. Here, we present a heat flow map at 1:3,500,000 scale, produced with heat flow data compiled from open data bases and previously unpublished data. The compiled heat flow data includes bottom hole temperature, temperature logs, transient temperature measurements and measured temperature logs. The new data were calculated from temperature gradient information and estimating a mean conductivity value characteristic for the type of rock present in the stratigraphic column or assigning the mean conductivity value for the crust. Geothermal gradient and the thermal resistivity (inverse thermal conductivity) were plotted and heat flow was calculated using the Bullard method. The map covers the whole continental territory of Mexico and shows that most of the country has values higher than the world average. The highest heat flow values are concentrated in two provinces: the Gulf of California extensional province and the Trans-Mexican Volcanic Belt.
\end{abstract}

Keywords: Geothermal; recent volcanism; renewable energy, geothermal gradient, Bullard method, BHT

\section{Resumen}

Los mapas de flujo de calor son una poderosa herramienta en la exploración regional de recursos geotérmicos. México es uno de los principales productores de energía geotérmica y la búsqueda a nivel regional para descubrir nuevos recursos debería estar basada en los datos de flujo de calor. Aquí presentamos el mapa de flujo de calor a escala 1:3,500,000, que fue generado a partir de datos de flujo de calor compilados en bases de datos públicas, a los cuales se añadieron nuevos datos calculados por los autores. Los datos compilados para el cálculo del mapa de flujo de calor incluyen: temperatura de fondo de pozo (BHT), registros de temperatura en pozos (compilados y medidos en este trabajo), mediciones transientes de temperatura. Los datos que no han sido reportados previamente fueron calculados a partir de la determinación del gradiente de temperatura y la estimación de la conductividad térmica promedio para los tipos de roca reportados en la columna estratigráfica, o bien, en ausencia de la información acerca del tipo de roca, se asignó el valor promedio de la conductividad para la corteza. El gradiente geotérmico y la resistividad térmica (el inverso de la conductividad térmica) se graficaron para determinar el flujo de calor con el método de Bullard. El mapa cubre todo el territorio continental mexicano y muestra que en la mayor parte los valores de flujo de calor están por encima del flujo de calor promedio a nivel mundial. Los valores más altos de flujo de calor se concentran en la provincia extensional del Golfo de California y en la Faja Volcánica Trans-Mexicana.

Palabras clave: Geotermia; volcanismo reciente; energía renovable, gradiente geotérmico, método de Bullard, BHT

\footnotetext{
(C) R. M. Prol-Ledesma, J. L. Carrillo-de la Cruz, M. A. Torres-Vera, A. S. Membrillo-Abad and O. M. Espinoza-Ojeda. Published by Terra Digitalis. This is an Open Access article distributed under the terms of the Creative Commons Attribution License (https://creativecommons.org/licenses/by-nc-sa/4.0/),
}

which permits non-commencial sharing of the work and adaptions, provided the original work is properly cited and the new creations are licensed under identical terms.

*E-mail address: prol@unam.mx 


\section{Introduction}

The total heat flux through the Earth's surface has been quantified at $47 \pm 2 \mathrm{TW}$ (Davies \& Davies, 2010); while in 2017, the reported installed capacity in the world to produce electricity was a little more than $6 \mathrm{TW}$ (https://www.cia.gov/library/pu blications/the-world-factbook/rankorder/2236rank.html). This shows that the energy irradiated by the Earth's surface is almost 8 times the world installed capacity for electricity generation and could be harnessed to supply, at least a part of the world energy needs.

The surface heat flow is an indication of the transport of heat from the interior of the Earth and its value depends greatly on the transport mechanism as well as the heat production in the crust. In most of the crust, heat is transported conductively; however, in some areas the more efficient convective heat transport predominates. To have convection in the crust, a fluid must be allowed to ascend to the surface carrying the heat in the upper crust, this fluid is often water, but magma is the dominant fluid for heat transport from the lower crust and from the mantle. The hot water can be used to produce electricity, for climatization and industrial processes.

The evaluation of the geothermal potential of a country is often linked to a heat flow map (White \& Williams, 1975; Muffler \& Cataldi, 1978; Muffler, 1979; Blackwell et al., 2007; van Wees et al., 2013). Heat flow values delineate the areas where the temperature at depth potentially allows exploitation of the thermal energy with the available technology. Temperatures at depth can be calculated assuming a conductive model; in this case, it is necessary to know the value of the thermal conductivity of the rocks and its chemistry to estimate the heat production by the radioactive element content. Recent tectonic and volcanic activity plays a major role in the heat flow values; heat transport models show that the maximum value of heat flow, due to an igneous intrusion in the crust, is attained after 100,000 years if convection occurs, and when conduction prevails, heat flow would decrease exponentially one order of magnitude in 200,000 years (Norton \& Knight, 1977). Therefore, a heat flow map may provide evidence about the presence of heat sources based on heat transport models.

\section{Heat flow data}

Heat flow measurements are scarce in Mexico, despite being one of the ten countries with the highest electricity production from geothermal energy. Published heat flow maps of the region included data calculated with temperature measurements in wells (Blackwell \& Richards, 2004) but most of the heat flow reports were based on estimations, using diverse methods (Marvin, 1984; Prol-Ledesma \& Juárez, 1986; Campos-Enriquez et al., 1990; Prol-Ledesma, 1990, 1991b; Beltrán-Abaunza \& Quintanilla-Montoya, 2001; Prol-Ledesma \& Torres-Vera, 2007; Espinosa-Cardeña \& Campos-Enríquez, 2008; Manea \& Manea, 2010). Heat flow estimations are generally based on silica geothermometer, Curie Temperature Depth, and Helium isotopic ratio $\left({ }^{3} \mathrm{He} /{ }^{4} \mathrm{He}\right)$ (Swanberg \& Morgan, 1978; Okubo, 1985; Polyak, 2005). More recent estimations have included geological and geophysical information (Goutorbe et al., 2011).

The heat flow map presented in this work was constructed using only data calculated with temperatures measured in wells because other estimations are less reliable. In fact, silica concentration in spring/well water is indicative of temperature at depth, provided chemical equilibrium is attained, which is not always the case. Furthermore, a parameter that remains unknown is the equilibrium depth, which hinders an accurate calculation of thermal gradient. The relation between silica geothermometer and heat flow is only qualitative, the correlation coefficient is $<50 \%$ (Fig. 1) and should not be used as an exact determination to be included in thermal models.

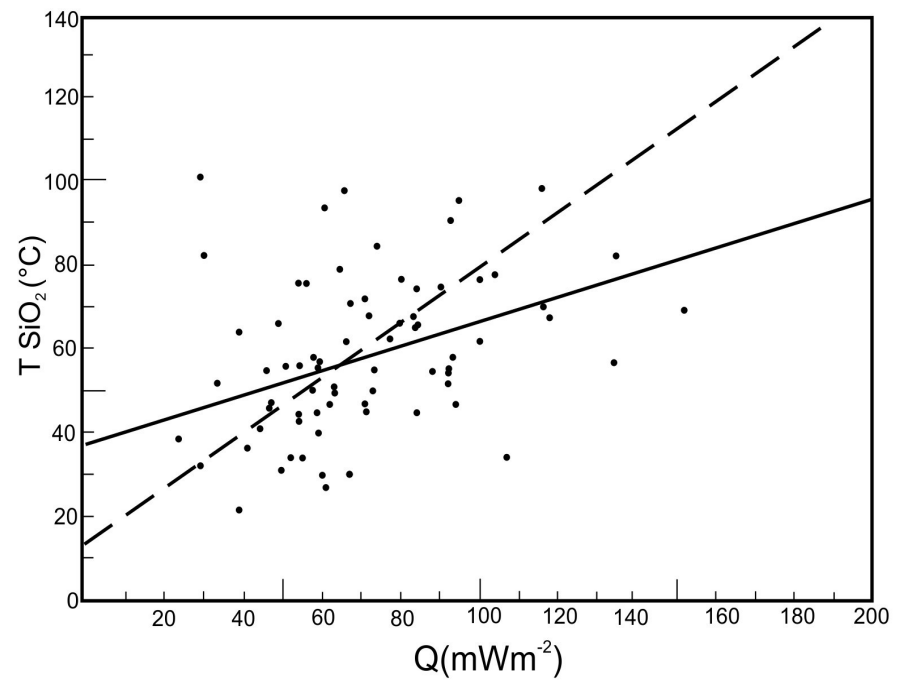

Figure 1. Plot of silica temperature vs heat flow (Modified from Swanberg \& Morgan, 1980).

Figura 1. Temperatura de sílice contra flujo de calor.

Similar ambiguity is present in heat flow estimations using the ${ }^{3} \mathrm{He} /{ }^{4} \mathrm{He}$ and Curie temperature depth (CTD). The comparison between measured heat flow and estimations calculated from CTD show significant differences in some areas (e.g. Manea \& Manea, 2010). According to Bouligand et al. (2009), discrepancies between heat flow and calculated CTD arise when thermal conductivities and/or heat generation are not well constrained; additionally, 3-D variations in thermal conductivity, rapid erosion or sedimentation, variations on radioactive heat production, heat provided by recent volcanism or groundwater circulation may cause large discrepancies. More importantly, in some cases the bottom of the magnetic sources may be a lithologic contact corresponding to the base of the crust and not the actual CTD; additionally, there might be artifacts associated to the acquisition of the data. In the classic paper on CTD, Okubo (1985) did not intend to calculate heat flow, but to produce a qualitative relation between shallow CTD and the occurrence of geothermal systems; further comparison of calculated CTD with geothermal gradient measurements produced signif- 
icant inconsistencies (Okubo et al., 1989). These discrepancies are also present in the estimation of the geothermal gradient of Cerro Prieto using CTD, yielding values ranging between 33 and $38^{\circ} \mathrm{C} / \mathrm{km}$ and a heat flow of $100 \mathrm{~mW} / \mathrm{m}^{2}$ (EspinosaCardeña \& Campos-Enríquez, 2008); while the reported well temperature (Lippmann et al., 1991) indicates a gradient higher than $100^{\circ} \mathrm{C} / \mathrm{km}$.

The relation between heat flow and ${ }^{3} \mathrm{He} /{ }^{4} \mathrm{He}$ is based on the assumption that high ${ }^{3} \mathrm{He} /{ }^{4} \mathrm{He}$ is caused by mantle upwelling and degassing that would produce high heat flow anomalies (Polyak, 1985; Polyak \& Tolstikhin, 1985; Polyak, 2005); however, the scattered data prevents a reliable quantitative correlation between both parameters (Fig. 2).

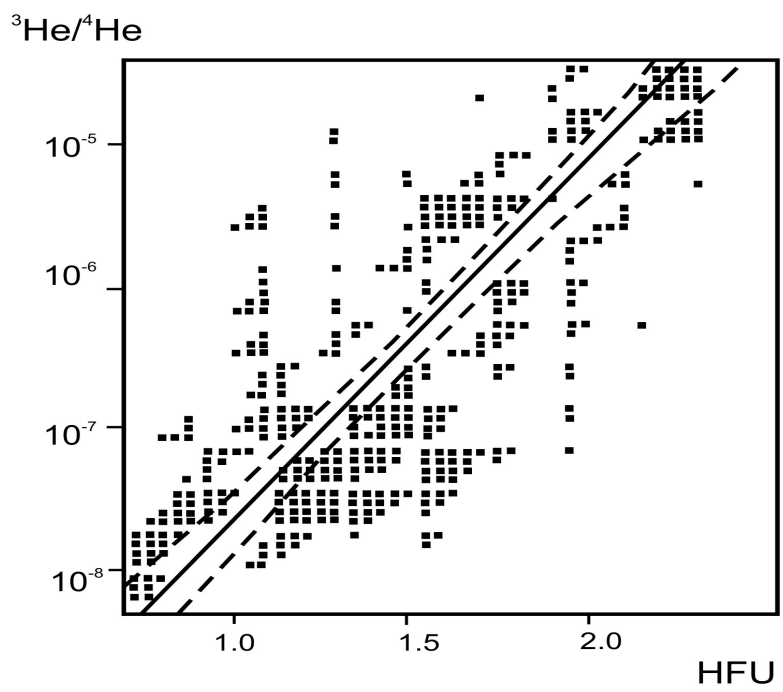

Figure 2. Plot of ${ }^{3} \mathrm{He} /{ }^{4} \mathrm{He}$ vs heat flow that shows the large scatter of the data. It also shows the best correlation between both parameters that would support calculation of heat flow with the isotopic helium ratio (after Polyak, 2005). Figura 2. ${ }^{3} \mathrm{He} /{ }^{4} \mathrm{He}$ contra flujo de calor mostrando la gran dispersión de los datos. También muestra la mejor correlación entre ambos parámetros, la cual soportaría el cálculo del flujo de calor a partir del cociente ${ }^{3} \mathrm{He} /{ }^{4} \mathrm{He}$.

At the beginning of the XXI century, the heat flow measurements reported in the continental part of Mexico (Smith, 1974; Smith et al., 1979; Reiter \& Tovar, 1982; Ziagos et al., 1985; Flores-Márquez et al., 1999) were more scarce than those in the ocean bottom, where more than 700 heat flow measurements were published (Becker \& Fisher, 1991; Epp et al., 1970; Fisher et al., 2001; Khutorskoy et al., 1990; Lawver \& Williams, 1979; Nagihara et al., 1996; Prol-Ledesma et al., 1989; Vacquier et al., 1967; Von Herzen,1963; Von Herzen \& Uyeda,1963). However, since the creation of the Mexican Center for Innovation in Geothermal Energy (CeMIE-Geo), a great effort has been made to compile and produce more heat flow data and construct a reliable heat flow map to assist the evaluation of the geothermal potential of the country (Espinoza-Ojeda et al., 2017 a,b; Neumann et al., 2017; Prol-Ledesma et al., 2013; Prol-Ledesma et al., 2016; Prol-Ledesma, 2018). The compilation of all available data to calculate the geothermal gradient and the measurement of temperature in wells, produced a large increase in the number of data. Heat flow data assembled for this work are available in public data bases: Heat Flow Database (http://www. datapages.com/gis-map-publishing-program/gis-open-files/glo bal-framework/global-heat-flow-database), Pangea database (ht tps://doi.pangaea.de/10.1594/PANGAEA.810104), the International Heat Flow Commission [IHFC] (http://engineering.und. edu/geology-and-geological-engineering/globe-heat-flow-data base/index.cfm), and the SMU Geothermal Lab database (https: //www.smu.edu/Dedman/Academics/Programs/GeothermalLab /DataMaps).

Additionally, temperature data in wells were measured by our group to calculate heat flow using estimated values for thermal conductivity. In other cases we obtained drilling information for some previously reported data that allowed recalculating the borehole stable temperature (Appendix Table 1). When the temperature logs were available, the data were reviewed and analyzed; in some cases, they were reprocessed to calculate the borehole stable temperature and the heat flow based on the Bullard Method. In all cases the confidence of the data was estimated. The data were discarded when the correlation coefficient obtained by the Bullard Method was lower than $90 \%$. A table of the recalculated and previously unreported data used in the map is included as supplemental online material with references to the original publications (Appendix Table 1). Here, we present the map produced by the interpolation of all heat flow data (Plate 1). The interpolation was achieved using the methodology described in this work. This map represents all heat flow data in Mexico available to date and it will be continually updated.

\section{Tectonic Framework}

The tectonic structure of Mexico is quite complex, as it is formed of diverse terranes (Campa \& Coney, 1983; Sedlock et al., 1993), many of them allochthonous, whose relations are obscured by the widely distributed Cenozoic volcanic products (Morán-Zenteno, 1986). It is precisely the widely spread Cenozoic volcanic-tectonic activity that determines the thermal regime of most geological provinces, especially the Neogene and Quaternary volcanism (Morán-Zenteno et al., 2007). This activity is better related to the physiographic provinces (Fig. 3 ) than to the tectono-stratigraphic terrains, and the numerous surface hydrothermal manifestations are evidence of the extensive thermal anomalies (Appendix Figure 1). Figure 3 includes recent $(<3 \mathrm{My})$ volcanism because the current models used for geothermal exploration (Moeck \& Beardsmore, 2014) consider that one of the geological settings for "viable" or "active" geothermal systems may be related to igneous activity with age $<3 \mathrm{My}$ (Pleistocene and Holocene volcanism in https:// volcano.si.edu/, intraplate volcanism in Aranda-Gómez et al., 2005; Ferrari et al., 2005, 2007; Vidal-Solano et al., 2005).

The main Cenozoic geodynamic events (Fig. 3) are the subduction of the Farallon Plate in western Mexico, the cessation of subduction after the approaching of the oceanic ridge with 


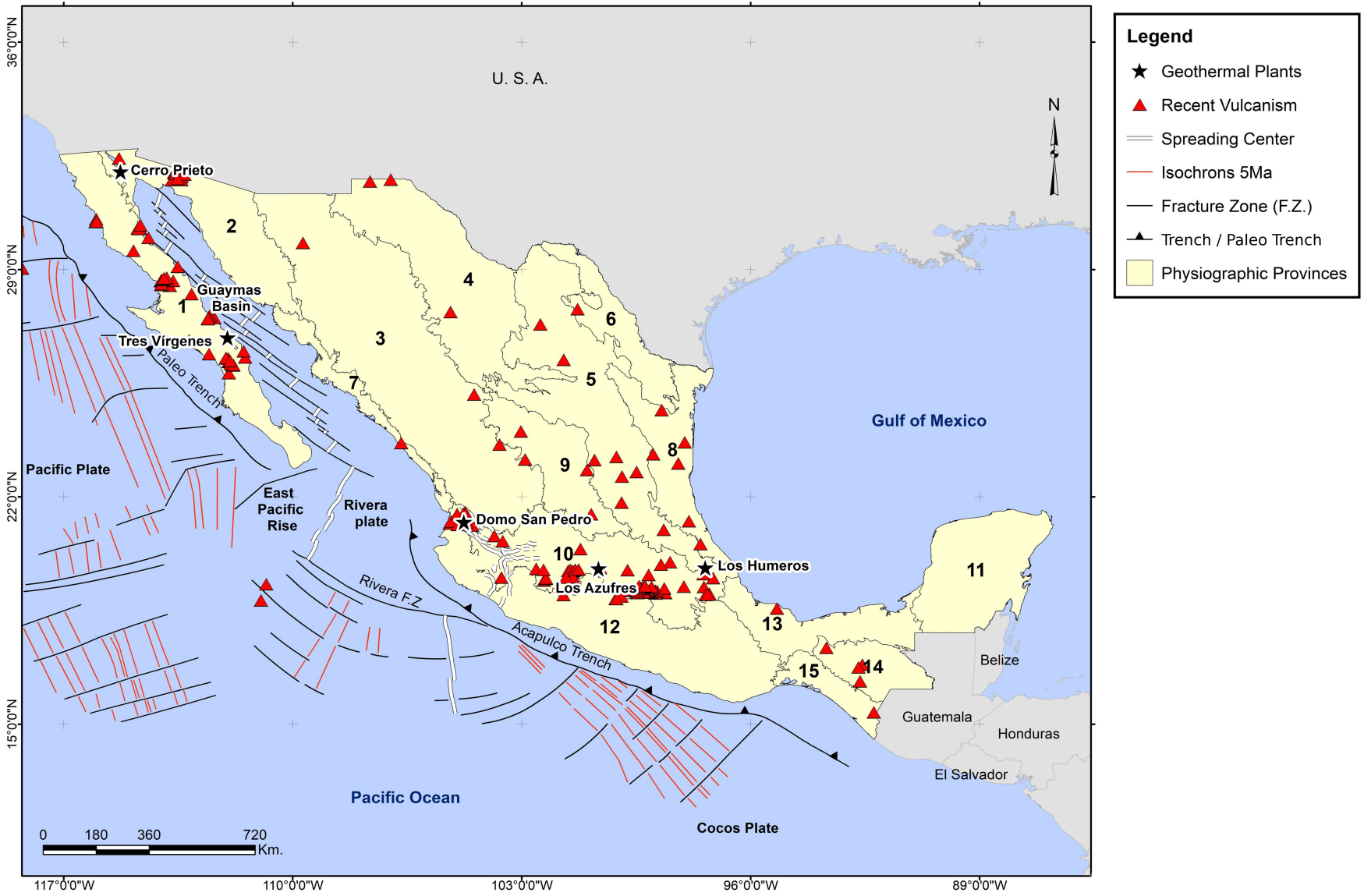

Figure 3. Main morpho-tectonic features of the pacific oceanic floor (modified after INEGI, 2001 and Padilla, 2013). The distribution of physiographic provinces of México and volcanic features $<3$ My are also shown. 1. Baja California Peninsula; 2. Sonora Plains; 3. Sierra Madre Occidental; 4. Basin and range province; 5. Sierra Madre Oriental; 6. North America Plains; 7. Pacific Coastal Plains; 8. Gulf of Mexico coastal plains-north ; 9. Mesa Central Province; 10. Mexican Volcanic Belt; 11. Yucatán Peninsula; 12. Sierra Madre del Sur; 13. Gulf of Mexico coastal plains-south; 14. Sierra de Chiapas - Guatemala; 15. Central America Volcanic Belt. Volcanism with age < 3My after: https://volcano.si.edu/, intraplate volcanism after Aranda-Gómez et al., 2005; Ferrari et al., 2005, 2007; Vidal-Solano et al., 2005.

Figura 3. Rasgos morfotectónicos del piso oceánico del Pacífico. Distribución de las provincias fisiográficas en México y centros volcánicos de $<3$ Ma. 1. Península de Baja California; 2. Planicie de Sonora; 3. Sierra Madre Occidental; 4. Provincia de cuencas y sierras; 5. Sierra Madre Oriental; 6. Planicie de Norte América; 7. Planicie de la Costa del Pacífico; 8. Planicie al norte del Golfo de Mexico ; 9. Provincia de la Mesa Central ; 10. Cinturón Volcánico Mexicano; 11. Península de Yucatán; 12. Sierra Madre del Sur; 13. Planicie al sur del Golfo de Mexico; 14. Sierra de Chiapas - Guatemala; 15. Cinturón Volcánico de Centro América.

the trench and the extensional regime associated with these processes that culminate in the opening of the Gulf of California. On the other hand, subduction of the Rivera and the Cocos Plates continues beneath the central and south-western part of Mexico (Atwater, 1970). These events produced geologic provinces like the Sierra Madre Occidental, the Trans-Mexican Volcanic Belt and the formation of the continental rift, locally evolved to ocean spreading, in the Gulf of California. The Cerro Prieto geothermal field is linked to this latter geodynamic process (Fig. 3). Extensional tectonics is also observed in the western part of Mexico, where a late Cenozoic rift triple junction (Jalisco Triple Junction) delineates the Jalisco Block. These rifts are associated with Plio-Quaternary alkaline and peralka- line volcanics, typical of continental rifting processes (Allan et al., 1991). An interesting feature in the west-central part of southern Mexico, is the Orozco Fracture Zone (OFZ) that is subducted below the Tzitzio Gap (Blatter and Hammersly, 2010), where some hydrothermal systems have been recently reported (Jácome-Paz et al., 2018). In addition to the extensional tectonics in the Gulf of California and subduction in southwestern Mexico, intraplate-type volcanism, often associated with normal faulting (late Oligocene-Quaternary), is widespread in the northern and central parts of Mexico (ArandaGómez et al., 2005) and to the east in the Gulf of Mexico coast (Ferrari et al., 2005). Heat flow positive anomalies appear to be linked to this type of volcanism. 


\section{Methodology}

\subsection{Heat flow calculation}

Heat flow is calculated using the Fourier equation that assumes conductive heat transport:

$$
q=-k(d T / d z)
$$

where $q$-heat flow; $k$-thermal conductivity; $T$-temperature and $z$-depth. Available temperature gradient information was analyzed for data screening of geothermal gradient data. This screening was performed to remove local convective effects, especially for those measurements located within hydrothermal systems, to determine the superficial regional conductive heat flow. This was achieved by analyzing the Bullard plots to establish the linear regression between thermal resistance and temperature gradient:

\section{MEX060}

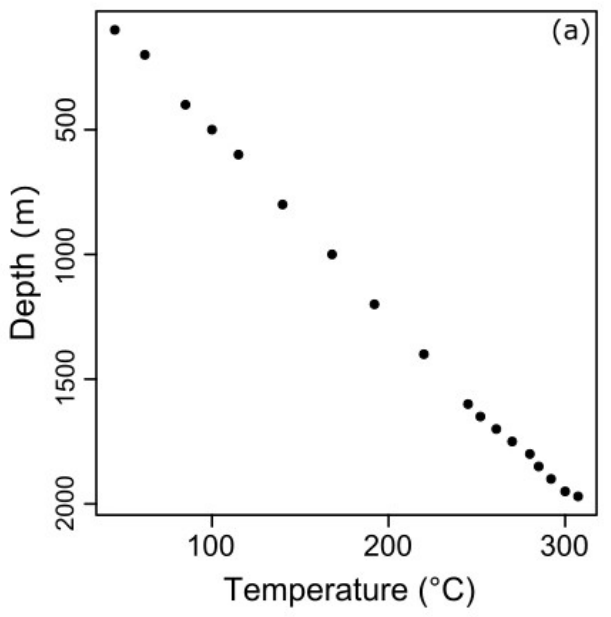

\section{MEX023}

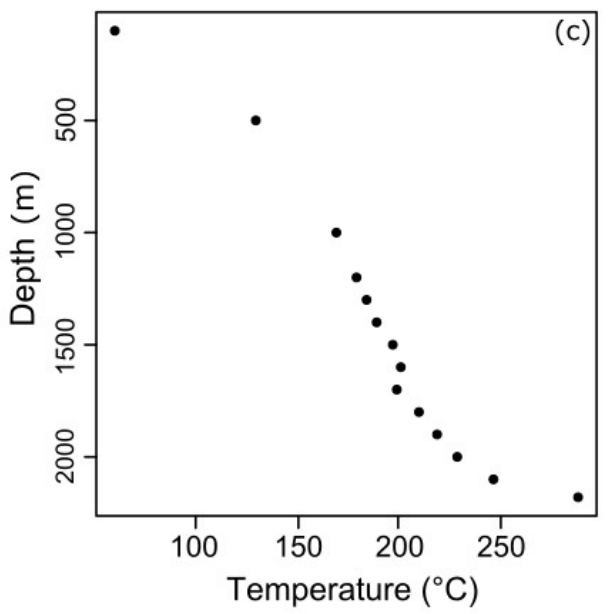

$$
T_{d}=T_{o}+q_{o} R
$$

where $T_{d}$ is temperature at depth, $T_{o}$ is the temperature at surface, $q_{o}$ is the surface heat flow and $R$ is thermal resistance expressed as:

$$
R=\sum_{i}\left(\frac{\Delta z_{i}}{k_{i}}\right)
$$

where $k_{i}$ is the thermal conductivity over the $i$-th stratigraphic interval at depth and $\Delta z_{i}$ is the thickness of the interval.

As an example, Figure 4a shows temperature increases linearly with depth for well MEX060; this linear relationship is preserved in the dependence between the temperature and thermal resistance in the Bullard plot of Figure $4 \mathrm{~b}$.

On the other hand, Figures $4 \mathrm{c}$ and $4 \mathrm{~d}$ show temperature plots for well MEX023; high resolution temperature logs are
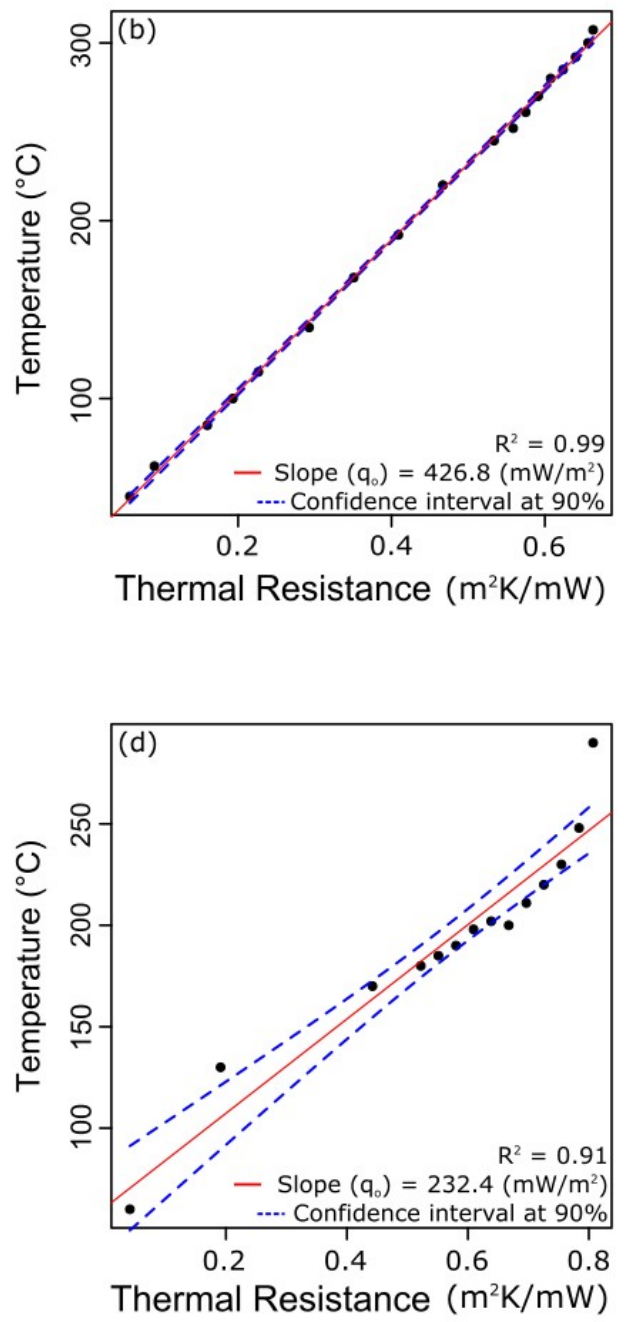

Figure 4. a) Temperature-depth profile and b) Bullard Plot from well MEX060. c) Temperature-depth profile and d) Bullard Plot from well MEX023. Figura 4. a) Perfil temperatura-profundidad y b) Gráfico Bullard del pozo MEX060. c) Perfil temperatura-profundidad y d) Gráfico Bullard del pozo MEX023. 
very useful to identify disturbances in the conductive regime within the well, but the Bullard plot allows to estimate heat flow and the confidence of the slope determination.

The well data used to calculate heat flow by the Bullard Method satisfy parameters of reliability proposed by Richards et al. (2012). Some of these parameters are: (1) the "normal" gradient conditions may be found below 200 meters depth, and (2) multiple gradient intervals are assigned to thermal conductivity values using a weighted average.

The error in the presented new heat flow data can be calculated from the correlation coefficient for each well. A well disturbed by a convection flow has a low correlation coefficient. Accordingly, disturbed wells with a correlation coefficient below $90 \%$ were discarded. Only undisturbed wells with a coefficient correlation above $90 \%$ were considered for the construction of the map. Disturbed data are easy to identify in high resolution temperature logs using a gradient-depth plot. However, wells with few data are more difficult to analyze for identification of convection disturbances (Beck \& Balling, 1988; Cull \& Sparksman, 1977); therefore, wells with few data and low correlation coefficients were discarded. All new heat flow data included in the Appendix Table 1, have an accuracy of more than $90 \%$ with a positional accuracy of $\pm 50 \mathrm{~m}$.

\subsection{Interpolation}

The interpolation was performed using the Inverse Distance Weighting algorithm (IDW). IDW estimates an unknown value of $z$ at location $u$ as a weighted average of its surrounding points, in which the weight is the inverse of the distance raised to a power, according to Tobler's first law of geography (Chang, 2004; Wang, 2006). The observations of $z$ at points closer to $u$ have a higher weight in the interpolation than those at a greater distance (Brunsdon \& Comber, 2015).

The algorithm is defined as:

$$
z_{u}=\frac{\sum_{i=1}^{s} z_{i} d_{u i}^{-k}}{\sum_{i=1}^{s} d_{u i}^{-k}}
$$

where:

- $z_{u}$ is the unknown heat flow value to be estimated at location $\mathrm{u}$.

- $z_{i}$ is the heat flow value at control point $i$.

- $d_{u i}$ is the distance between points $\mathrm{i}$ and $\mathrm{u}$.

$-s$ is the number of points used in the calculation

$-k$ is the power the distance is raised to.

In the IDW algorithm, the power controls the weight function decrease rate with increasing distance (Bonham-Carter, 1994).

IDW is used in Earth Sciences when the data set does not present a smooth variation but contains large anomalies (Setianto \& Triandini, 2013). Other methods, like Kriging, smooth the interpolated values and the anomalies are discarded. In exploration work, the anomalies are frequently the target for the discovery of natural resources (Shepard, 1968), as is the case in geothermal exploration; therefore, the selection of the IDW method agrees with the purpose of the map (Plate 1).

\subsection{Evaluation of the error in the interpolation process}

The evaluation of the error utilized the mean squared error (MSE) method to assess the differences between the actual heat flow measurements and the estimation calculated with the interpolation. The plot that represents the actual heat flow values and the associated interpolated value is shown in Figure 5.

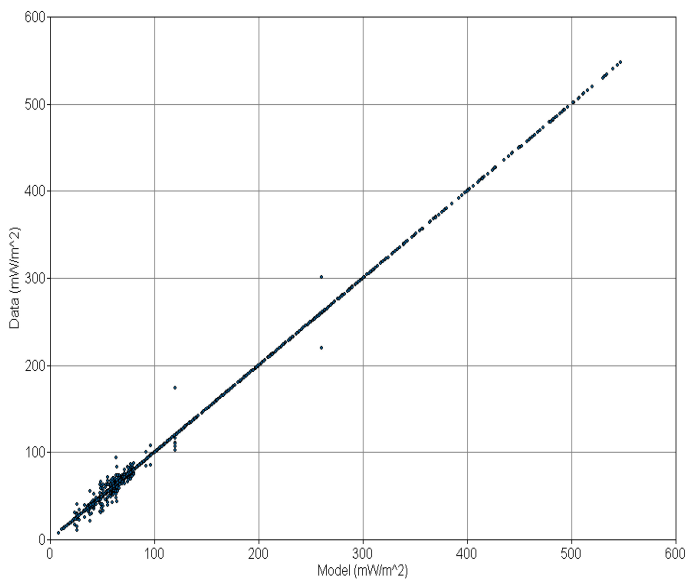

Figure 5. Error plot. The actual heat flow data values are plotted vs the modelled values in the simulation. See text for details.

Figura 5. Gráfico de error. Los valores reales de flujo de calor están graficados contra los valores de la simulación. Ver texto para detalles.

These values were used to calculate the MSE that yields a value of $4.96 \%$ for the map, which validates the interpolation process. Figure 6 represents the error obtained for all points in the map.

\section{Map Synopsis}

The interpolation of all the available heat flow measurements for the continental region of Mexico indicates that high heat flow is prevalent in extensive areas in Mexico, and prospective zones are found outside of the active Mexican Volcanic Belt, where so far, most exploration work has been carried out. Three geothermal fields have been developed within the Mexican Volcanic Belt and two in the Baja California Peninsula (Fig. 3 and Plate 1). However, large areas with heat flow at least twice the world mean value have not been explored yet.

The map shows a correlation between high heat flow and recent thermal events related with volcanic-tectonic activity especially in the western and central parts of Mexico, where active subduction, sea floor spreading, and continental rifting is taking place; however, new regions where no exploration campaigns have taken place are pointed out in the map as future targets. 


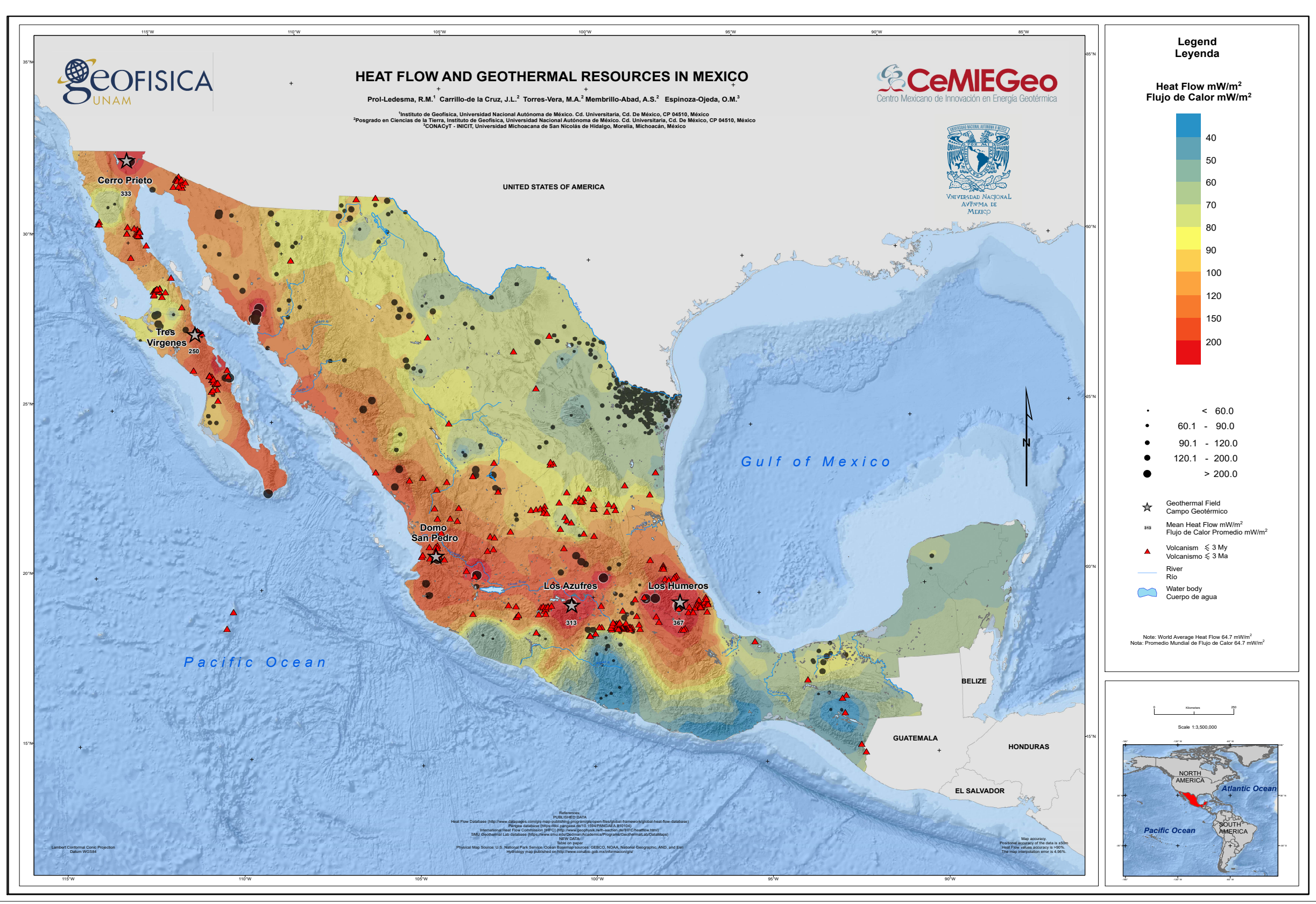




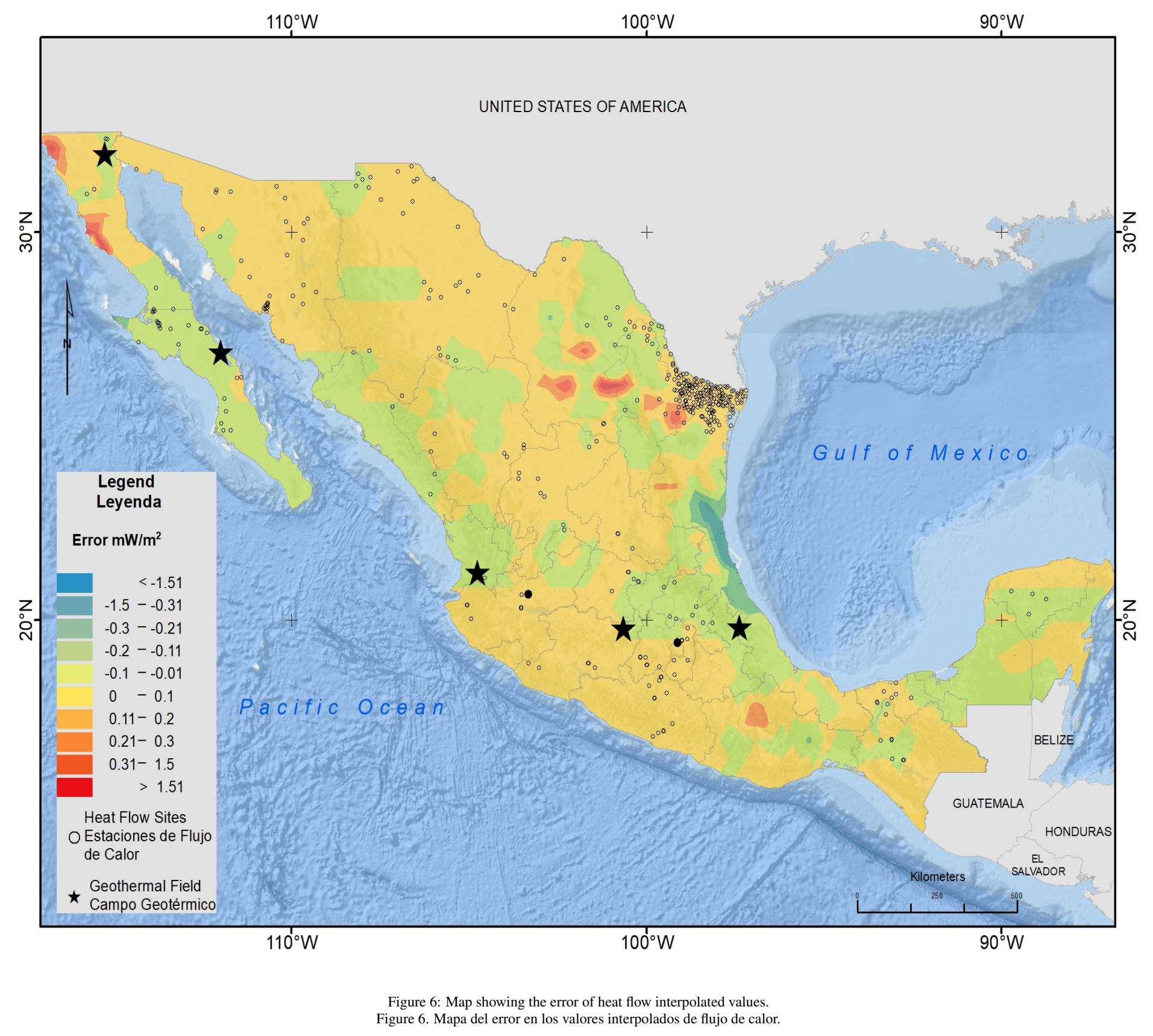


The average heat flow for continents is $64.7 \mathrm{~mW} \cdot \mathrm{m}^{-2}$ (Davies, 2013), and a large part of Mexico presents heat flow values over $100 \mathrm{~mW} \cdot \mathrm{m}^{-2}$. This fact suggests that Mexico's geothermal potential has not been exhausted yet and that more intense exploration should be pursued in the newly appointed areas. In contrast, heat flow values, as low as $13 \mathrm{~mW} \cdot \mathrm{m}^{-2}$, have been measured in the Pacific coast region as a result of subduction of the oceanic plate (Ziagos et al., 1985); these areas are characterized by a deep Curie isotherm, between 16 and $24 \mathrm{~km}$ (Manea $\&$ Manea, 2010).

The Baja California Peninsula exhibits large areas with high heat flow above $100 \mathrm{~mW} \cdot \mathrm{m}^{-2}$. Two geothermal fields are currently under exploitation (Fig. 3 and Plate 1) but regional exploration indicates that the geothermal energy potential may be above 400 MWe (Arango-Galván et al., 2015), and the heat flow map confirms that large resources occur in this region. Heat flow is high along the eastern coast of the Gulf of California as evidence of the sea floor spreading processes taking place nearby.

The eastern part of central Mexico stands out with heat flow values above $150 \mathrm{~mW} \cdot \mathrm{m}^{-2}$. Part of this area corresponds to the limits of the Trans-Mexican Volcanic Belt, but the northern and southern sections are related to high thermal gradients within the oil fields, in some wells the thermal gradient is above 50$70^{\circ} \mathrm{C} / \mathrm{km}$ (Eguiluz-de Antuñano, 2009).

The Sierra Madre Occidental and the intraplate recent volcanic features in the central and eastern parts of Mexico represent the least studied high heat flow anomalies in Mexico (ProlLedesma, 2018), and a possible target for future geothermal exploration.

The southeastern part of Mexico contains the oldest provinces as the Oaxaca Terrain (Campa \& Coney, 1983) and at the same time it hosts active volcanoes: El Chichon and Tacana; the heat flow measurements have been performed in areas with predominance of the old terrains thermal regime where low heat flow values predominate; nevertheless, high heat flow data in the northern part of this area influence nearby zones as evidence of hotter than average areas.

\section{Conclusions}

The heat flow values indicate that a large part of Mexico contains promising areas for exploitation and direct utilization of geothermal energy. The most important result is that geothermal exploration should be continued in a regional basis focused on the heat flow anomalies revealed by this map.

The heat flow map will be indispensable for the definition of the geothermal provinces of Mexico, which will guide exploration in the future to fully develop the geothermal resources. Undoubtedly, the future increase in heat flow measurements is necessary and will reveal major high heat flow anomalies in large areas that remain uncharted.

\section{Software}

We developed our own programs to calculate the well stable temperature and to apply the Bullard method used to compute the new heat flow data. The interpolation process was performed with the IDW algorithm in ESRI ArcGIS.

\section{Map Design}

The coordinate system used for the map is WGS 84 (World Geodetic System 1984) that locates sites by Latitude, Longitude and Elevation. In this map we will use only Lat/Long to locate the heat flow sites. Geographic coordinates can be used for the whole country without much distortion. We used shape files of Countries from Wessel \& Smith (2017). We used the ArcMap platform for administration of geographic data.

- Scale 1:3,500,000 and interpolation was performed in A0.

- Map is oriented to the geographic north

- The total area is $1,881,032 \mathrm{Km}^{2}$

- Grade spacing: $5^{\circ} 0^{\prime} 0.0^{\prime \prime}$

\section{Acknowledgements}

The authors wish to thank J. Miguel Flores Velazquez, Marcela Errasti-Orozco, Claudia Arango, José Luis Salas, Xóchitl Flores and Juan Antonio Tapia for their help in collecting and processing the data. This work was supported by Fondo de Sustentabilidad Energética SENER-CONACyT CeMIE-Geo under Grant-Project P-01: Mapas de Gradiente Geotérmico y Flujo de Calor para la República Mexicana". The authors thank the comments by two anonymous reviewers that greatly improve the original manuscript.

\section{References}

Allan, J. F., Nelson, S. A., Luhr, J. F., Carmichael, I. S. E., Wopat, M., Wallace, P. J., 1991. Pliocene-Holocene Rifting and Associated Volcanism in Southwest Mexico: An Exotic Terrane in the Making: Chapter 21: Part III. Regional Geophysics and Geology 114, 425-445, doi:10.1306/M47542C21.

Aranda-Gómez, J. J., Luhr, J. F., Housh, T. B., Valdez-Moreno, G., ChávezCabello, G., Aranda-Gómez, J. J., Luhr, J. F., Housh, T. B., Valdez-Moreno, G., Chávez-Cabello, G., 2005. El volcanismo tipo intraplaca del Cenozoico tardío en el centro y norte de México: una revisión. Boletín de la Sociedad Geológica Mexicana 57 (3), 187-225, doi:10.18268/bsgm2005v57n3a1.

Arango-Galván, C., Prol-Ledesma, R. M., Torres-Vera, M. A., 2015. Geothermal prospects in the Baja California Peninsula. Geothermics 55, 39-57, doi:10.1016/j.geothermics.2015.01.005.

Atwater, T., Dec. 1970. Implications of Plate Tectonics for the Cenozoic Tectonic Evolution of Western North America. GSA Bulletin 81 (12), 35133536, doi:10.1130/0016-7606(1970)81[3513:IOPTFT]2.0.CO;2.

Beck, A. E., Balling, N., 1988. Determination of Virgin Rock Temperatures. Solid Earth Sciences Library. Springer Netherlands, Dordrecht, doi:10.1007/978-94-009-2847-3_3.

Becker, K., Fisher, A. T., 1991. A Brief Review of Heat-Flow Studies in the Guaymas Basin, Gulf of California: Chapter 33: Part VI. Hydrothermal Processes. American Association of Petroleum Geologist Memoir 47, 709720. 
Beltrán-Abaunza, J. M., Quintanilla-Montoya, A. L., Mar. 2001. Calculated heat flow for the ensenada region, baja california, mexico. Ciencias Marinas 27 (4), 619-634, doi:10.7773/cm.v27i4.497.

Blackwell, D. D., Negraru, P. T., Richards, M. C., Dec. 2006. Assessment of the Enhanced Geothermal System Resource Base of the United States. Natural Resources Research 15 (4), 283-308, doi:10.1007/s11053-007-9028-7.

Blackwell, D. D., Richards, M. C., 2004. Geothermal map of North America: Scale 1:6,500,000. Am. Assoc. Petrol. Geol., product Code 423.

Blatter, D. L., Hammersley, L., 2010. Impact of the Orozco Fracture Zone on the central Mexican Volcanic Belt. Journal of Volcanology and Geothermal Research 197 (1), 67-84, doi:10.1016/j.jvolgeores.2009.08.002.

Bonham-Carter, G. F., 1994. Geographic Information Systems for Geoscientists: Modelling with GIS. Elsevier, Canada, google-Books-ID: FkKeBQAAQBAJ.

Bouligand, C., Glen, J. M. G., Blakely, R. J., 2009. Mapping Curie temperature depth in the western United States with a fractal model for crustal magnetization. Journal of Geophysical Research: Solid Earth 114 (B11), doi:10.1029/2009JB006494.

Brunsdon, C., Comber, L., 2015. An Introduction to R for Spatial Analysis and Mapping. SAGE, google-Books-ID: ViCJCwAAQBAJ.

Campa, M. F., Coney, P. J., Jun. 1983. Tectono-stratigraphic terranes and mineral resource distributions in Mexico. Canadian Journal of Earth Sciences 20 (6), 1040-1051, doi:10.1139/e83-094.

Campos-Enriquez, J. O., Arroyo-Esquivel, M. A., Urrutia-Fucugauchi, J., Jan. 1990. Basement, Curie isotherm and shallow-crustal structure of the TransMexican Volcanic Belt, from aeromagnetic data. Tectonophysics 172 (1), 77-90, doi:10.1016/0040-1951(90)90060-L.

Chang, K.T,, 2004. Introduction to geographic information systems, 2nd Edition. McGraw-Hill.

Cull, J., Sparksman, G., 1977. Measurements of Surface Heat Flow. Bureau of Mineral Resources Geology and Geophysics Record 12 (39), 1-17.

Davies, J. H., 2013. Global map of solid Earth surface heat flow. Geochemistry, Geophysics, Geosystems 14 (10), 4608-4622, doi:10.1002/ggge.20271.

Davies, J. H., Davies, D. R., 2010. Earth's surface heat flux. Solid Earth 1 (1), 5-24, doi:10.5194/se-1-5-2010.

De Anda, L. F., Septien, J. I, Elizondo, J. R., 1964. Geothermal energy in Mexico. Proceedings of the UN Conference on New Sources of Energy 2, 149165, new York; United Nations.

Eguiluz-de Antuñano, S., 2009. The Yegua Formation: Gas Play in the Burgos Basin, Mexico, in C. Bartolini, and J. R. Roman Ramos, eds., Petroleum systems in the southern Gulf of Mexico:. American Association of Petroleum Geologist Memoir 90, 49-77, doi:10.1306/13191077M902621.

Epp, D., Gnim, P. J., Langseth, M. G., Oct. 1970. Heat flow in the Caribbean and Gulf of Mexico. Journal of Geophysical Research 75 (29), 5655-5669, doi:10.1029/JB075i029p05655.

Espinosa-Cardeña, J. M., Campos-Enriquez, J. O., Oct. 2008. Curie point depth from spectral analysis of aeromagnetic data from Cerro Prieto geothermal area, Baja California, México. Journal of Volcanology and Geothermal Research 176 (4), 601-609, doi:10.1016/j.jvolgeores.2008.04.014.

Espinoza-Ojeda, O. M., Prol-Ledesma, R. M., Iglesias, E. R., 2017a. Continental heat flow data update for México - Constructing a reliable and accurate heat flow map, in Proceddings of the 42nd Workshop on Geothermal Reservoir Engineering 2017: Stanford, California, USA, 13-15 February 2017SGP-TR-212.

Espinoza-Ojeda, O. M., Prol-Ledesma, R. M., Iglesias, E. R., Figueroa-Soto, A., 2017b. Update and review of heat flow measurements in México. Energy 121, 466-479, doi:10.1016/j.energy.2017.01.045.

Ferrari, L., Tagami, T., Eguchi, M., Orozco-Esquivel, M. T., Petrone, C. M., Jacobo-Albarrán, J., López-Martínez, M., 2005. Geology, geochronology and tectonic setting of late Cenozoic volcanism along the southwestern Gulf of Mexico: The Eastern Alkaline Province revisited. Journal of Volcanology and Geothermal Research 146 (4), 284-306, doi:10.1016/j.jvolgeores.2005.02.004.

Ferrari, L., Valencia-Moreno, M., Bryan, S., 2007. Magmatism and tectonics of the Sierra Madre Occidental and its relation with the evolution of the western margin of North America. In: Special Paper 422: Geology of México: Celebrating the Centenary of the Geological Society of México. Vol. 422. Geological Society of America, pp. 1-39, doi:10.1130/2007.2422(01).

Fisher, A. T., Giambalvo, E., Sclater, J., Kastner, M., Ransom, B., Weinstein,
Y., Lonsdale, P., 2001. Heat flow, sediment and pore fluid chemistry, and hydrothermal circulation on the east flank of Alarcon Ridge, Gulf of California. Earth and Planetary Science Letters 188 (3), 521-534, doi:10.1016/S0012821X(01)00310-7.

Flores-Márquez, E.L., Chávez-Segura, R., Campos-Enríquez, O., Pilkington, M., 1999. Preliminary 3-D structural model from the Chicxulub impact crater and its implications in the actual geothermal regime. Trends in Heat, Mass and Momentum Transfer 5, 19-40.

García-Estrada, G., 2000. Modelado del estado térmico inicial del campo geotérmico de Los Azufres, Michoacán, México. PhD Thesis. Universidad Nacional Autónoma de México, Posgrado en Ciencias de la Tierra, UNAM, http://132.248.9.195/pd2000/285393/Index.html.

Goutorbe, B., Poort, J., Lucazeau, F., Raillard, S., 2011. Global heat flow trends resolved from multiple geological and geophysical proxies. Geophysical Journal International 187 (3), 1405-1419, doi:10.1111/j.1365246X.2011.05228.x.

Iglesias, E.R., Torres, R.J., Martinez-Estrella, J.I., Reyes-Picasso, N., 2015. Summary of the 2014 Assessment of Medium- to Low-Temperature Mexican Geothermal Resources. In World Geothermal Congress, 16-24 April 2015, Australia-New Zealand: proceedingsPaper 16081, 7pp.

Instituto Nacional de Estadística, Geografía e Informática (INEGI), 2001. Conjunto de datos vectoriales Fisiográficos. Continuo Nacional escala 1:1,000,000 serie I. Provincias fisiográficas. INEGI, http://www.beta.inegi.org.mx/temas/mapas/fisiografia/.

Japan International Cooperation Agency (JICA), 1989. Evaluación del yacimiento geotérmico en La Primavera. JICA, $122 \mathrm{pp}$.

Jácome-Paz, M.P., Pérez-Zárate, D., Prol-Ledesma, R.M., Rodríguez-Díaz, A.A., Estrada-Murillo, A.M., González-Romo, I. A., Magaña-Torres, E., 2018. Two new geothermal prospects in the Mexican Volcanic Belt: La Escalera and Agua Caliente-Tzitzio geothermal springs, Michoacán, México(submitted).

Khutorskoy, M. D., Fernandez, R., Kononov, V. I., Polyak, B. G., Matveev, V. G., Rot, A. A., 1990. Heat flow through the sea bottom around the Yucatan Peninsula. Journal of Geophysical Research: Solid Earth 95 (B2), 12231237, doi:10.1029/JB095iB02p01223.

Lawver, L. A., Williams, D. L., 1979. Heat flow in the central Gulf of California. Journal of Geophysical Research: Solid Earth 84 (B7), 3465-3478, doi:10.1029/JB084iB07p03465.

Lippmann, M. J., Truesdell, A. H., Halfman-Dooley, S. E., A., M., 1991. A review of the hydrogeologic-geochemical model for Cerro Prieto. Geothermics 20 (1-2), 39-52, doi:10.1016/0375-6505(91)90004-F.

Manea, M., Manea, V. C., 2010. Curie Point Depth Estimates and Correlation with Subduction in Mexico. Pure and Applied Geophysics 168 (8), 14891499, doi:10.1007/s00024-010-0238-2.

Marvin, P.R., 1984. Regional heat flow based on the silica content of ground waters from northcentral Mexico. M.Sc. Thesis. New Mex. St. Univ., 107 p.

Moeck, I., Beardsmore, G., 2014. A New 'Geothermal Play Type' Catalog: Streamlining Exploration Decision Making. Proceedings. Thirty-Ninth Workshop on Geothermal Reservoir EngineeringStanford, California: Stanford University; p. 8.

Morán-Zenteno, D., 1986. Breve revisión sobre la evolución tectónica de México. Geofísica Internacional 25 (1), 9-38.

Morán-Zenteno, D.J., Cerca, M., Keppie, J.D., 2007. The Cenozoic tectonic and magmatic evolution of southwestern México: Advances and problems of interpretation, in Alaniz-Álvarez, S.A. \& Nieto-Samaniego, Á.F., eds., Geology of México: Celebrating the Centenary of the Geological Society of México. Geological Society of America Special Paper 422, 71-91, doi:10.1130/2007.2422(03).

Muffler, P., 1979. Assessment of geothermal resources of the United States-1978. U.S.G.S. Circular 790.

Muffler, P., Cataldi, R., 1978. Methods for regional assessment of geothermal resources. Geothermics 7 (2), 53-89, doi:10.1016/0375-6505(78)90002-0.

Nagihara, S., Sclater, J. G., Phillips, J. D., Behrens, E. W., Lewis, T., Lawver, L. A., Nakamura, Y., Garcia-Abdeslem, J., Maxwell, A. E., 1996. Heat flow in the western abyssal plain of the Gulf of Mexico: Implications for thermal evolution of the old oceanic lithosphere. Journal of Geophysical Research 101 (B2), 2895-2913, doi:10.1029/95JB03450.

Neumann, F., Negrete-Aranda, R., Harris, R. N., Contreras, J., Sclater, J. G., González-Fernández, A., Dec. 2017. Systematic heat flow measurements 
across the Wagner Basin, northern Gulf of California. Earth and Planetary Science Letters 479, 340-353, doi:10.1016/j.eps1.2017.09.037.

Norton, D., Knight, J. E., 1977. Transport phenomena in hydrothermal systems; cooling plutons. American Journal of Science 277 (8), 937-981, doi:10.2475/ajs.277.8.937.

Okubo, Y., Graf, R., Hansen, R., Ogawa, K., Tsu, H., 1985. Curie point depths of the Island of Kyushu and surrounding areas, Japan. GEOPHYSICS 50 (3), 481-494, doi:10.1190/1.1441926.

Okubo, Y., Tsu, H., Ogawa, K., 1989. Estimation of Curie point temperature and geothermal structure of island arcs of Japan. Tectonophysics 159 (3), 279-290, doi:10.1016/0040-1951(89)90134-0.

Padilla y Sánchez, R., Domínguez Trejo, I., López Azcárraga, A., Mota Nieto, J., Fuentes Menes, A., Rosique Naranjo, F., Germán Castelán, E., Campos Arriola, S., 2013. National Autonomous University of Mexico Tectonic Map of Mexico GIS Project, American Association of Petroleum Geologists GIS Open Files series.

Polyak, B. G., 2005. Heat and mass transfer from the mantle: heat flow and He-isotope constraints. Annals of Geophysics 48 (1), 9-17.

Polyak, B. G., Kononov, V. I., Kamensky, I., Prasolov, E. M., Sharkov, I. V., Prol-Ledesma, R. M., Gonzalez, A., Razo, A., Molina-Berbeller, R., 1985. First estimations of terrestrial heat flow in the TMVB and adjacent areas based on isotopic composition of natural helium. Geofisica Internacional 24 (4), 465-476.

Polyak, B. G., Tolstikhin, I. N., 1985. Isotopic composition of the earth's helium and the problem of the motive forces of tectogenesis. Chemical Geology: Isotope Geoscience section 52 (1), 9-33, doi:10.1016/0168-9622(85)900053.

Prol-Ledesma, R. M., 1990. Mapa geotérmico de la República Mexicana. Atlas Nacional de México. Vol. 3. Instituto de Geografía, UNAM.

Prol-Ledesma, R. M., 1991a. Chemical geothermometers applied to the study of thermalized aquifers in Guaymas, Sonora, Mexico: a case history. Journal of Volcanology and Geothermal Research 46 (1), 49-59, doi:10.1016/03770273(91)90075-B.

Prol-Ledesma, R. M., 1991b. Terrestrial Heat Flow in Mexico. In: Čermák, V., Rybach, L. (Eds.), Terrestrial Heat Flow and the Lithosphere Structure. Exploration of the Deep Continental Crust. Springer Berlin Heidelberg, Berlin, Heidelberg, pp. 475-485, doi:10.1007/978-3-642-75582-8_24.

Prol-Ledesma, R. M., 2018. Anomalías de flujo de calor terrestre y la definición de la provincia geotérmica asociada al volcanismo de intraplaca en México. Trabajo de Ingreso a la Academia de Ingeniería México. Http://www.ai.org.mx/presentacion/anomalías-de-flujo-decalor-terrestre-y-la-definición-de-la-provincia-geotérmica.

Prol-Ledesma, R. M., Arango-Galván, C., 2017. Sistemas Geotérmicos de la Península de Baja California. Vol. 21. Monografías del Instituto de Geofísica, UNAM, $233 \mathrm{pp}$.

Prol-Ledesma, R. M., Espinoza-Ojeda, O.M., Iglesias, E.R., Arango-Galván, C., 2016. Integration of heat flow measurements and estimations in the construction of Mexico's heat flow map. Proceedings European Geothermal Congress 2016Strasbourg, France, 19-24 Sept.

Prol-Ledesma, R. M., Juarez, G., 1986. Geothermal map of Mexico. Journal of Volcanology and Geothermal Research 28 (3), 351-362, doi:10.1016/03770273(86)90030-2.

Prol-Ledesma, R. M., Sugrobov, V. M., Flores, E. L., Juárez M., G., Smirnov, Y. B., Gorshkov, A. P., Bondarenko, V. G., Rashidov, V. A., Nedopekin, L. N., Gavrilov, V. A., 1989. Heat flow variations along the Middle America Trench. Marine Geophysical Researches 11 (1), 69-76, doi:10.1007/BF00286248.

Prol-Ledesma, R. M., Torres-Vera, M. A., 2007. Mapa de Recursos Geotérmicos de la República Mexicana. Atlas Nacional de México. Instituto de Geografía, UNAM. E-VI-3.

Prol-Ledesma, R. M., Torres-Vera, M.-A., Rodolfo-Metalpa, R., Ángeles, C., Lechuga Deveze, C. H., Villanueva-Estrada, R. E., Shumilin, E., Robinson, C., 2013. High heat flow and ocean acidification at a nascent rift in the northern Gulf of California. Nature Communications 4, 1388, doi: $10.1038 /$ ncomms 2390 .

Reiter, M., Tovar R., J. C., 1982. Estimates of terrestrial heat flow in northern Chihuahua, Mexico, based upon petroleum bottom-hole temperatures. GSA Bulletin 93 (7), 613-624, doi:10.1130/00167606(1982)93<613:EOTHFI >2.0.CO;2.

Richards, M., Blackwell, D., Williams, M., Frone, Z., Dingwall, R., Batir, J., Chickering, C., 2012. Proposed Reliability Code for Heat Flow Sites. GRC Transactions 36.

Sedlock, R.L., Ortega-Gutiérrez, F., Speed, C., 1993. Tectonostratigraphic Terranes and Tectonic Evolution of Mexico. Geological Society of America Special Paper 278, 153 p. doi:10.1130/SPE278-p1.

Setianto, A., Triandini, T., 2013. COMPARISON OF KRIGING AND INVERSE DISTANCE WEIGHTED (IDW) INTERPOLATION METHODS IN LINEAMENT EXTRACTION AND ANALYSIS. Journal of Applied Geology 5 (1), 21-29, doi:10.22146/jag.7204.

Shepard, D., 1968. A two-dimensional interpolation function for irregularlyspaced data. Proceedings of the 1968 ACM National Conference,517-524. doi:10.1145/800186.810616.

Smith, D. L., 1974. Heat flow, radioactive heat generation, and theoretical tectonics for northwestern Mexico. Earth and Planetary Science Letters 23 (1), 43-52, doi:10.1016/0012-821X(74)90028-4.

Smith, D. L., Nuckels, C. E., Jones, R. L., Cook, G. A., 1979. Distribution of heat flow and radioactive heat generation in northern Mexico. Journal of Geophysical Research: Solid Earth 84 (B5), 2371-2379, doi:10.1029/JB084iB05p02371.

Swanberg, C. A., Morgan, P., 1978. The linear relation between temperatures based on the silica content of groundwater and regional heat flow: A new heat flow map of the United States. Pure and Applied Geophysics 117 (1), 227-241, doi:10.1007/BF00879749.

Swanberg, C. A., Morgan, P., 1980. The silica heat flow interpretation technique: Assumptions and applications. Journal of Geophysical Research: Solid Earth 85 (B12), 7206-7214, doi:10.1029/JB085iB12p07206.

Vacquier, V., Sclater, J.G., Corry, C.F., 1967. Studies of the thermal state of the Earth. 21st paper. Heat Flow, Eastern Pacific. 45, 375-393.

Van Wees, J.D., Boxem, T., Calcagno, P, Dezayes, C., Lacasse, C., Manzella, A., 2013. A Methodology for Resource assessment and application to core countries. Deliverable no. 2.1 (final). GEO-ELEC project, 28 pp.

Vidal-Solano, J.R., Paz Moreno, F.A., Demant, A., 2005. Caracterización y Cronologia del Evento Volcánico Terciario Pre-Pinacate, Campo El Pinacate, Noroeste de Sonora, Mexico. Bol. Depto. Geol. UniSon 18-19, $117-140$.

Von Herzen, R. P., 1963. Geothermal Heat Flow in the Gulfs of California and Aden. Science 140 (3572), 1207-1208, doi:10.1126/science.140.3572.1207.

Von Herzen, R. P., Uyeda, S., 1963. Heat flow through the eastern Pacific ocean floor. Journal of Geophysical Research 68 (14), 4219-4250, doi:10.1029/JZ068i014p04219.

Wang, F., 2006. Quantitative Methods and Applications in GIS. CRC Press, doi: $10.1201 / 9781420004281$.

White, D. E., Williams, D. L., 1975. Assessment of geothermal resources of the United States-1975. U.S. Geological Survey Circular 726, 155 p.

Wilhelm, H., Heidinger, P., Safanda, J., Cermák, V., Burkhardt, H., Popov, Y., 2004. High resolution temperature measurements in the borehole Yaxcopoil-1, Mexico. Meteoritics \& Planetary Science 39, 813-819. doi:10.1111/j.1945-5100.2004.tb00931.x.

Ziagos, J. P., Blackwell, D. D., Mooser, F., 1985. Heat flow in southern Mexico and the thermal effects of subduction. Journal of Geophysical Research: Solid Earth 90 (B7), 5410-5420, doi:10.1029/JB090iB07p05410.

This article accompanies the following material:

HTML:

Static map:
DOI: 10.22201/igg.25940694.2018.2.51.103

DOI: 10.22201/igg.25940694.2018.2.51.104 


\section{Appendix}

\section{Appendix Table 1. Data table (unpublished)}

New and revised heat flow data are included in Table 1. We used published temperature logs and BHT (a - García-Estrada, 2000; b - De Anda et al., 1964; c - Prol-Ledesma, 1991a; d - JICA, 1989; e - Lippmann et al., 1991 ; f - Espinoza-Ojeda et al., 2017; g - Wilhelm et al., 2004) as well as temperature data measured by our group to calculate the geothermal gradient. Heat flow was calculated following the methodology explained in this paper. Thermal conductivity was estimated based on lithology, and when lithology was not reported for the well, we assigned the crust average conductivity value $\left(2.5 \mathrm{~W} / \mathrm{m}^{\circ} \mathrm{K}\right)$. All new and recalculated data presented in Table 1 were included in the heat flow map produced here. The columns of the table include: data number, original site ID, temperature data source (reference), site location in geographic coordinates, calculated geothermal gradient $\left({ }^{\circ} \mathrm{C} / \mathrm{km}\right)$, conductivity $\left(\mathrm{W} / \mathrm{m}{ }^{\circ} \mathrm{K}\right.$; estimated from lithology or average crust value “*”), heat flow $\left(\mathrm{mW} / \mathrm{m}^{2}\right)$.

Appendix Table 1. New heat flow data produced by temperature gradient measurement (Grad-T-this work); temperature gradient from references (Grad-T-a,b,...) and recalculation of heat flow data with additional information (Rec-f). Thermal conductivity based on well lithology or crustal average $(*) /$ Tabla 1 del apéndice. Nuevos datos de flujo de calor producidos a partir de mediciones de gradiente de temperatura (Grad-T- este trabajo); gradiente de temperatura de referencias (Grad$\mathrm{T}-\mathrm{a}, \mathrm{b}, . .$. ) y nuevos cálculos de datos de flujo de calor con información adicional (Rec-f). La conductividad térmica se tomó de la litología del pozo o bien del valor promedio de la corteza $(*)$.

\begin{tabular}{|c|c|c|c|c|c|c|c|c|}
\hline Data \# & $\begin{array}{c}\text { Data } \\
\text { production }\end{array}$ & Site ID & Long. & Lat. & $\begin{array}{l}\text { Depth } \\
\text { (m) }\end{array}$ & $\begin{array}{l}\text { Geoth. Grad. } \\
\text { (C/Km) }\end{array}$ & $\begin{array}{l}\text { Conductivity } \\
\text { (W/mK) }\end{array}$ & $\begin{array}{c}\text { Heat Flow } \\
\left(\mathbf{m W} / \mathbf{m}^{2}\right)\end{array}$ \\
\hline 1 & Grad-T-this work & Fraile 1 & -101.33430 & 25.02550 & 334 & 20.0 & $2.50 *$ & 50.1 \\
\hline 2 & Grad-T-this work & Difuntita & -101.19090 & 25.06305 & 509 & 28.5 & $2.50^{*}$ & 71.2 \\
\hline 4 & Grad-T-a & 1 & -100.66489 & 19.79216 & 2159 & 139.7 & 1.87 & 261.3 \\
\hline 5 & Grad-T-a & 3 & -100.68695 & 19.80533 & 2440 & 99.3 & 1.84 & 182.3 \\
\hline 6 & Grad-T-a & 12 & -100.67013 & 19.79218 & 898 & 256.6 & 1.87 & 479.8 \\
\hline 9 & Grad-T-a & 19 & -100.66752 & 19.82438 & 1663 & 154.8 & 1.87 & 289.4 \\
\hline 10 & Grad-T-a & 21 & -100.67644 & 19.82662 & 1705 & 153.7 & 1.87 & 287.4 \\
\hline 11 & Grad-T-a & 22 & -100.66094 & 19.78968 & 1246 & 215.5 & 2.17 & 467.6 \\
\hline 12 & Grad-T-a & 23 & -100.67494 & 19.79773 & 1729 & 141.8 & 1.87 & 265.1 \\
\hline 13 & Grad-T-a & 25 & -100.66305 & 19.79787 & 1600 & 182.2 & 1.75 & 318.9 \\
\hline 14 & Grad-T-a & 26 & -100.65038 & 19.79787 & 1240 & 201.8 & 1.77 & 356.5 \\
\hline 15 & Grad-T-a & 31 & -100.64631 & 19.78205 & 1295 & 221.6 & 1.87 & 414.4 \\
\hline 20 & Grad-T-a & 44 & -100.68244 & 19.82122 & 2440 & 88.7 & 1.87 & 165.9 \\
\hline 21 & Grad-T-a & 46 & -100.66807 & 19.78246 & 970 & 258.0 & 1.87 & 482.4 \\
\hline 22 & Grad-T-a & 47 & -100.66438 & 19.78621 & 2957 & 102.9 & 1.89 & 194.5 \\
\hline 23 & Grad-T-a & 48 & -100.66403 & 19.82548 & 2669 & 93.2 & 1.87 & 174.3 \\
\hline 24 & Grad-T-a & 49 & -100.65831 & 19.81669 & 2400 & 126.1 & 1.87 & 235.9 \\
\hline 25 & Grad-T-a & 51 & -100.66252 & 19.83178 & 1842 & 158.9 & 1.87 & 297.1 \\
\hline 26 & Grad-T-a & 53 & -100.66228 & 19.82938 & 1201 & 201.0 & 1.87 & 375.8 \\
\hline 27 & Grad-T-a & 54 & -100.68695 & 19.81525 & 898 & 211.2 & 1.87 & 395.0 \\
\hline 28 & Grad-T-a & 55 & -100.65800 & 19.78985 & 1403 & 206.1 & 1.87 & 385.4 \\
\hline 29 & Grad-T-a & 56 & -100.67200 & 19.81009 & 2305 & 113.2 & 1.87 & 211.7 \\
\hline 30 & Grad-T-a & 57 & -100.67038 & 19.82422 & 1722 & 156.8 & 1.87 & 293.3 \\
\hline 31 & Grad-T-a & E1 & -100.72993 & 19.82779 & 1995 & 94.8 & 1.87 & 177.3 \\
\hline 32 & Grad-T-a & E2 & -100.71824 & 19.80483 & 1992 & 106.5 & 1.87 & 199.2 \\
\hline
\end{tabular}




\begin{tabular}{|c|c|c|c|c|c|c|c|c|}
\hline 41 & Grad-T-c & 7 & -110.73610 & 28.09105 & 98 & 49.7 & $2.50^{*}$ & 124.2 \\
\hline 42 & Grad-T-c & 8 & -110.77607 & 28.02966 & 61 & 94.6 & $2.50 *$ & 236.6 \\
\hline 43 & Grad-T-c & 9 & -110.74538 & 28.01253 & 89 & 36.0 & $2.50^{*}$ & 90.1 \\
\hline 44 & Grad-T-c & 10 & -110.67899 & 28.14601 & 149 & 103.1 & $2.50^{*}$ & 257.8 \\
\hline 45 & Grad-T-d & PR2 & -103.53115 & 20.66423 & 1988 & 114.9 & 2.17 & 249.3 \\
\hline 46 & Grad-T-d & PR8 & -103.52068 & 20.66012 & 1855 & 137.3 & 2.24 & 307.5 \\
\hline 47 & Grad-T-d & PR10 & -103.51935 & 20.66183 & 2086 & 107.0 & 1.99 & 213.0 \\
\hline 48 & Grad-T-d & PR11 & -103.52418 & 20.65634 & 2125 & 77.7 & 2.24 & 174.1 \\
\hline 49 & Grad-T-e & M203 & -115.18686 & 32.39283 & 3958 & 114.4 & 2.42 & 277.0 \\
\hline 50 & Rec-f & MEX001 & -115.34450 & 32.44840 & 1825 & 18.0 & 2.86 & 51.5 \\
\hline 51 & Rec-f & MEX002 & -115.34500 & 32.43200 & 2200 & 11.7 & $2.50^{*}$ & 29.3 \\
\hline 52 & Rec-f & MEX003 & -111.41250 & 26.25000 & 500 & 12.5 & 2.55 & 31.9 \\
\hline 53 & Rec-f & MEX004 & -111.53500 & 26.24000 & 500 & 50.8 & $2.50^{*}$ & 126.9 \\
\hline 54 & Rec-f & MEX006 & -103.52694 & 20.29167 & 1950 & 29.1 & $2.50^{*}$ & 72.8 \\
\hline 55 & Rec-f & MEX007 & -103.53333 & 20.32278 & 800 & 49.4 & 2.07 & 102.0 \\
\hline 56 & Rec-f & MEX010 & -103.51889 & 20.65639 & 2271 & 125.6 & 2.12 & 266.3 \\
\hline 57 & Rec-f & MEX011 & -104.69500 & 21.11667 & 1911 & 102.5 & 2.50 & 256.3 \\
\hline 58 & Rec-f & MEX012 & -104.72917 & 21.08333 & 200 & 53.2 & $2.50^{*}$ & 133.0 \\
\hline 59 & Rec-f & MEX013 & -104.71667 & 21.10000 & 430 & 103.6 & $2.50^{*}$ & 259.0 \\
\hline 60 & Rec-f & MEX014 & -104.54942 & 21.09294 & 2801 & 29.2 & 2.32 & 67.5 \\
\hline 61 & Rec-f & MEX015 & -104.70167 & 21.18750 & 1911 & 52.4 & 3.05 & 159.7 \\
\hline 62 & Rec-f & MEX017 & -112.55622 & 27.50772 & 2500 & 69.0 & 2.48 & 171.3 \\
\hline 63 & Rec-f & MEX018 & -112.55890 & 27.50643 & 2505 & 94.6 & 2.37 & 224.3 \\
\hline 64 & Rec-f & MEX019 & -112.53444 & 27.49995 & 1250 & 133.8 & 2.33 & 311.9 \\
\hline 65 & Rec-f & MEX022 & -97.45561 & 19.66426 & 1810 & 203.0 & 2.09 & 424.0 \\
\hline 66 & Rec-f & MEX023 & -97.44878 & 19.64046 & 2300 & 74.0 & 3.14 & 232.4 \\
\hline 67 & Rec-f & MEX024 & -97.46761 & 19.69002 & 1670 & 230.8 & 2.10 & 484.6 \\
\hline 68 & Rec-f & MEX025 & -97.45516 & 19.68642 & 1880 & 90.8 & 2.08 & 188.5 \\
\hline 69 & Rec-f & MEX027 & -97.45619 & 19.67156 & 2310 & 152.7 & 2.22 & 338.8 \\
\hline 70 & Rec-f & MEX028 & -97.45859 & 19.67629 & 2350 & 141.5 & 2.09 & 295.4 \\
\hline 71 & Rec-f & MEX030 & -97.45383 & 19.67615 & 2160 & 123.6 & 2.20 & 272.4 \\
\hline 72 & Rec-f & MEX031 & -97.44904 & 19.68564 & 2480 & 212.0 & 2.17 & 459.5 \\
\hline 73 & Rec-f & MEX032 & -97.43770 & 19.64594 & 3100 & 165.9 & 2.41 & 399.4 \\
\hline 74 & Rec-f & MEX036 & -97.45157 & 19.69623 & 2265 & 164.8 & 2.15 & 354.1 \\
\hline 75 & Rec-f & MEX037 & -97.42717 & 19.63703 & 2903 & 98.5 & 2.14 & 210.7 \\
\hline 76 & Rec-f & MEX038 & -97.44618 & 19.67845 & 2292 & 225.7 & 2.20 & 496.6 \\
\hline 77 & Rec-f & MEX039 & -97.44182 & 19.68603 & 2402 & 236.6 & 2.12 & 501.5 \\
\hline 78 & Rec-f & MEX040 & -97.45165 & 19.70603 & 2220 & 134.3 & 2.28 & 305.8 \\
\hline 79 & Rec-f & MEX041 & -97.47294 & 19.69864 & 1500 & 189.6 & 2.56 & 485.8 \\
\hline 80 & Rec-f & MEX042 & -97.43386 & 19.66764 & 2620 & 167.6 & 2.30 & 385.5 \\
\hline 81 & Rec-f & MEX043 & -97.42156 & 19.64476 & 3270 & 109.7 & 2.23 & 245.1 \\
\hline 82 & Rec-f & MEX044 & -97.44875 & 19.68839 & 2577 & 155.7 & 2.19 & 341.4 \\
\hline 83 & Rec-f & MEX045 & -97.45558 & 19.68937 & 2200 & 120.5 & 2.43 & 293.2 \\
\hline 84 & Rec-f & MEX047 & -97.45598 & 19.70020 & 1926 & 173.3 & 2.13 & 369.8 \\
\hline 85 & Rec-f & MEX048 & -97.44844 & 19.69112 & 2200 & 162.3 & 2.09 & 339.9 \\
\hline 86 & Rec-f & MEX050 & -97.44533 & 19.68354 & 1800 & 209.3 & 2.21 & 462.4 \\
\hline 87 & Rec-f & MEX051 & -97.46339 & 19.69418 & 1700 & 234.6 & 2.20 & 515.5 \\
\hline 88 & Rec-f & MEX052 & -97.44914 & 19.68528 & 1800 & 216.7 & 2.04 & 442.7 \\
\hline 89 & Rec-f & MEX055 & -97.44185 & 19.64813 & 2500 & 84.3 & 2.21 & 186.2 \\
\hline 90 & Rec-f & MEX057 & -97.43990 & 19.64801 & 2200 & 173.1 & 2.11 & 364.8 \\
\hline 91 & Rec-f & MEX058 & -97.44226 & 19.65002 & 2200 & 184.4 & 2.17 & 400.5 \\
\hline 92 & Rec-f & MEX059 & -97.46233 & 19.69116 & 2200 & 192.2 & 2.57 & 493.3 \\
\hline 93 & Rec-f & MEX060 & -98.14294 & 19.92120 & 2000 & 143.5 & 2.98 & 426.8 \\
\hline 94 & Rec-f & MEX061 & -98.13815 & 19.92339 & 1900 & 107.2 & 2.46 & 263.2 \\
\hline 95 & Rec-f & MEX064 & -113.02362 & 25.98614 & 2244 & 25.1 & 2.19 & 55.0 \\
\hline 96 & Rec-f & MEX065 & -111.84375 & 25.37281 & 3014 & 26.1 & 2.45 & 63.9 \\
\hline 97 & Rec-f & MEX066 & -111.92245 & 24.88475 & 2500 & 32.4 & 2.36 & 76.5 \\
\hline 98 & Rec-f & MEX067 & -111.72009 & 24.89025 & 2657 & 29.3 & 2.66 & 77.9 \\
\hline 99 & Rec-f & MEX068 & -113.73551 & 27.65183 & 2405 & 34.9 & 1.90 & 66.3 \\
\hline 100 & Rec-f & MEX069 & -114.88719 & 28.29299 & 2811 & 28.1 & $2.50^{*}$ & 70.3 \\
\hline 101 & Rec-f & MEX071 & -111.88591 & 25.70630 & 3300 & 17.9 & 2.21 & 39.4 \\
\hline
\end{tabular}




\begin{tabular}{|c|c|c|c|c|c|c|c|c|}
\hline 102 & Rec-f & MEX072 & -113.71727 & 27.63163 & 2325 & 37.1 & 2.36 & 87.7 \\
\hline 103 & Rec-f & MEX073 & -114.51855 & 30.51737 & 3191 & 41.7 & 2.25 & 93.7 \\
\hline 104 & Rec-f & MEX074 & -113.91369 & 27.92988 & 3298 & 30.2 & 2.45 & 74.1 \\
\hline 105 & Rec-f & MEX075 & -115.03122 & 32.29032 & 3843 & 52.8 & 2.41 & 127.1 \\
\hline 107 & Rec-f & MEX077 & -114.27832 & 31.34619 & 3302 & 25.1 & $2.50 *$ & 62.7 \\
\hline 108 & Rec-f & MEX078 & -114.21425 & 31.37561 & 3300 & 27.1 & $2.50^{*}$ & 67.7 \\
\hline 109 & Rec-f & MEX079 & -113.87737 & 28.00498 & 1944 & 25.0 & 2.27 & 56.8 \\
\hline 110 & Rec-f & MEX080 & -113.40627 & 27.50679 & 3000 & 19.5 & 2.26 & 44.1 \\
\hline 113 & Rec-f & MEX083 & -113.70833 & 27.51782 & 1363 & 41.8 & 2.48 & 103.7 \\
\hline 114 & Rec-f & MEX084 & -113.38321 & 27.06762 & 4600 & 25.8 & $2.50 *$ & 64.5 \\
\hline 115 & Rec-f & MEX086 & -111.83968 & 25.37540 & 4424 & 17.4 & 2.22 & 38.5 \\
\hline 116 & Rec-f & MEX087 & -112.43983 & 25.76848 & 4505 & 25.6 & 2.19 & 56.0 \\
\hline 117 & Rec-f & MEX088 & -111.98696 & 25.07088 & 3762 & 33.4 & 2.11 & 70.4 \\
\hline 118 & Rec-f & MEX089 & -113.72808 & 27.58101 & 2750 & 34.3 & 2.29 & 78.6 \\
\hline 123 & Rec-f & MEX094 & -112.87839 & 29.63975 & 4813 & 59.6 & $2.50 *$ & 149.1 \\
\hline 124 & Rec-f & MEX095 & -113.75645 & 27.66715 & 2985 & 30.8 & $2.50 *$ & 77.0 \\
\hline 125 & Rec-f & MEX096 & -113.90057 & 27.95947 & 2636 & 31.5 & $2.50^{*}$ & 78.8 \\
\hline 126 & Rec-f & MEX097 & -114.65351 & 28.39972 & 4450 & 28.6 & $2.50^{*}$ & 71.5 \\
\hline 127 & Rec-f & MEX098 & -114.76003 & 32.37662 & 2918 & 29.9 & 2.57 & 76.9 \\
\hline 128 & Rec-f & MEX099 & -114.19423 & 31.26245 & 5591 & 23.3 & 2.47 & 57.4 \\
\hline 129 & Rec-f & MEX100 & -110.25876 & 27.18580 & 2471 & 30.7 & 2.36 & 72.5 \\
\hline 130 & Rec-f & MEX101 & -114.61628 & 31.80176 & 5325 & 27.2 & 2.49 & 67.7 \\
\hline 131 & Rec-f & MEX102 & -114.94561 & 32.00882 & 4530 & 35.0 & 2.55 & 89.1 \\
\hline 132 & Rec-f & MEX103 & -114.36411 & 31.62076 & 3872 & 33.3 & $2.50 *$ & 83.3 \\
\hline 133 & Rec-f & MEX104 & -114.75972 & 32.00861 & 5152 & 44.1 & $2.50 *$ & 110.3 \\
\hline 134 & Rec-f & MEX105 & -114.38430 & 31.79458 & 3887 & 29.4 & 2.42 & 71.2 \\
\hline 135 & Rec-f & MEX106 & -104.73863 & 28.88995 & 6509 & 31.9 & 2.24 & 71.3 \\
\hline
\end{tabular}


Appendix Figure 1

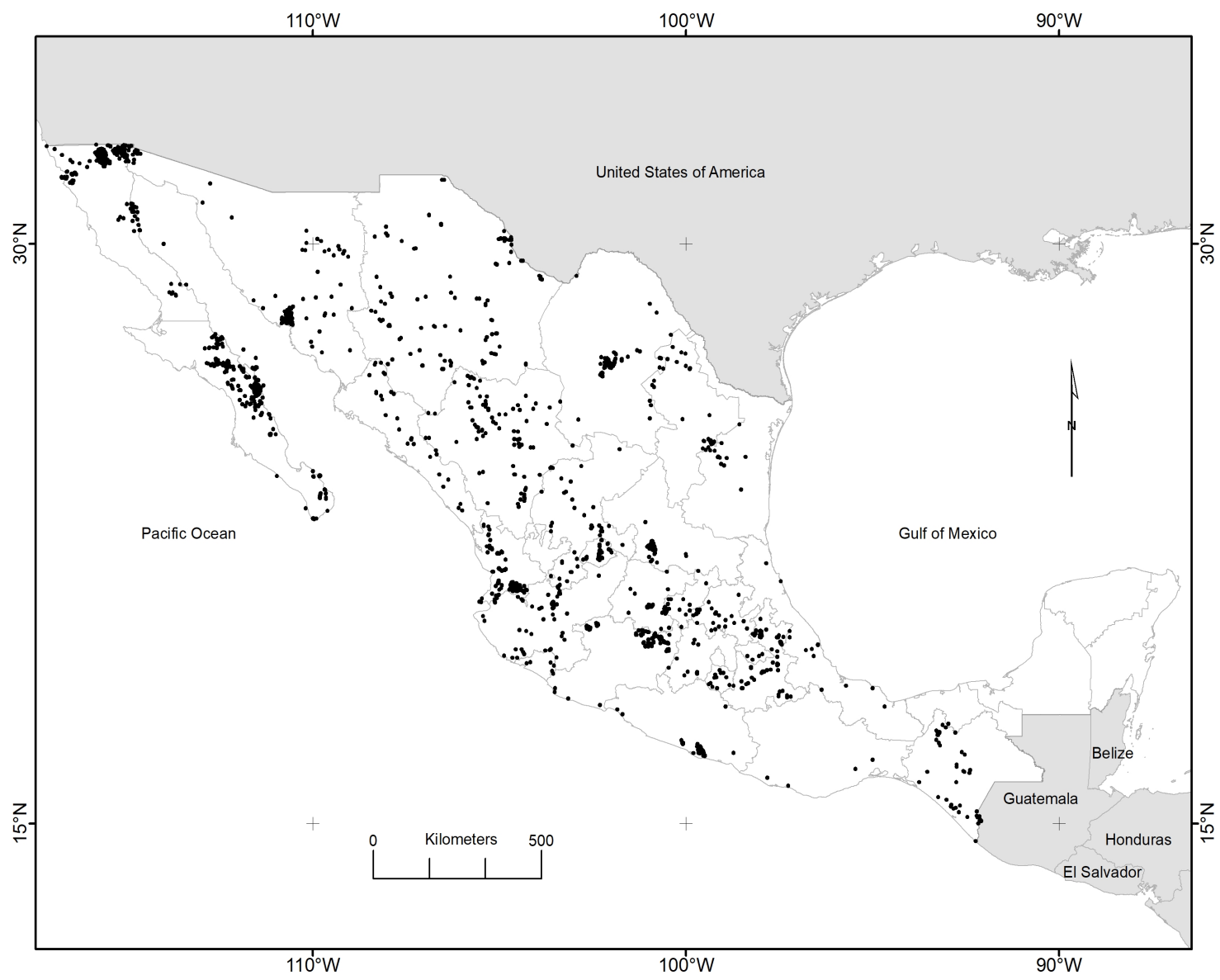

Appendix Figure 1. Map of hydrothermal manifestations in Mexico. (After: Iglesias et al., 2015; Prol-Ledesma \& Arango-Galván, 2017) / Figura 1 del apéndice. Mapa de las manifestaciones hidrotermales en México. 